\title{
"ESTRANGEIRADOS". A QUESTÃO DO ISOLACIONISMO PORTUGUÊS NOS SÉCULOS XVII E XVIII
}

\author{
Tiago C. P. dos Reis Miranda*
}

RESUMO - A análise das relaçièes culturais portuguesas no séculos XVII e XVIII é a base desse artigo. A preocupaçĩo em entender o papel dos "estrangeirados" e seus efeitos na corte portuguesa sẫo explorados através da revisâo de clocumentos de épocn e de uma revisão historiográfica. Os "estran. geiraclos" foram, no quadro português de entâo, intelectuais protegiclos pelo Estado atento a uma política de coerência cultural com o resto da Europa.

"Não me demorarei ante o quadro da miséria intelectual, política e econômica resultante da obra purificadora: muito levaria a deserever a Ilha da Purificação; referir-meei tão somente aos assaltos que pretenderam dar-lhe alguns Piratas beneméritos.

Apareceram, na verdade, estrangeiros e 'estrangeirados' que procuraram arrancar-nos ao nosso Isolamento. Foi, em Castela, a dinastia francesa e os seus homens; $e$ foram, entre nós, os 'estrangeirados' de que se serviu a vontade cega de Pombal."

António Sérgio ( $O$ problema da cultura e o isolamento dos povos peninsulares. Porto, Renascença Portuguesa. 1914, p. 30)

"...É relativamente recente, mas inegável, constituindo quase uma fractura da nossa imagem cultural, o sentimento de exílio, de distanciamento e, sobretudo, de autêntico e mórbido complexo de inferioridade em relação a uma outra Europa que, na esteira das descobertas hispânicas, iria reforȩar a sua revolução cultural - burguesia empreendedora, reforma religiosa, especialização científica - com a exploração económica sistemática dos nossos espaços extra-europeus. A estagnação ibérica é um facto incontestável, mas só o romantismo e,

\footnotetext{
* Pós-graduanto en História Social do Departamento de História/USP.
} 

XVII e XVIII.

sobretudo, a segunda revolução industrial lhe conferiram, no plano estritamente cultural, essa conotação deprimente, esse sentimento de desvalia que o Portugal e a Espanha dos séculos $X V I I$ e XVIII não viveram em termos de tão dramático ressentimento e hiperbólico fascinio."

Eduardo Lourenço (Nós e a Europa ou as duas razões, $2^{\circledR}$ ed. (Lisboa), Imprensa Nacional. (1988). p. 26).

Análises da cultura portuguesa nos séculos XVII e XVIII costumam referir um grupo de indivíduos particularmente receptivos a idéias vindas do exterior, que na altura se teriam conhecido de maneira pejorativa como "estrangeirados". Embora haja poucos trabalhos específicos sobre o assunto, é normal que ele desperte a imagem de uma Lisboa que se tornava decadente -"contemplativa" e "beata" -, fomentando uma enorme hostilidade em relação à Europa de além-Pirineus. Existe quem fale em "obscurantismo", "atraso" e "dependência"; no entanto, em alguns casos, tais noções podem chegar a contradizer-se... Torna-se pois necessário refletir sobre a história dessa apreciação negativa, para entender os momentos em que ela frutificou e, no mínimo, despertar atenções para a complexidade do problema. Talvez os "estrangeirados" possam oferecer uma linha de abordagem especialmente sugestiva.

1. Em última instância, o debate foi equacionado por António Sérgio e Jaime Cortesão, parceiros na Renascença Portuguesa e, mais tarde, na Seara Nova. Queria-se entāo exprimir um certo desagrado quanto às diretrizes políticas e culturais dos primeiros governos republicanos, fazendo circular uma mensagem revitalizadora e plural. Na década de vinte, chegou-se a assumir claramente o objetivo de "renovar a mentalidade da élite portuguesa, tornando-a capaz de um verdadeiro movimento de salvação" e "criar uma opinião pública nacional que exija e apoie as reformas necessárias..."1

Poucos levariam adiante essa finalidade pedagógica com o vigor de António Sérgio. Logo depois do seu ingresso na Renascença, deslocou-se em missão ao Rio de Janeiro para se encontrar com um grupo de intelectuais. Escreveu nesse momento o seu primeiro grande ensaio, que intitulou "O 
problema da cultura e o isolamento dos povos peninsulares". Com o objetivo de discutir a "crise moral" do país, mergulhava na história, reprovando a ascendência do espírito de conquista sobre o hábito da criação, e a atividade "purificadora" dos tribunais do Santo Ofício. Desde o século XVI, o autor acreditava que se fora perdendo o comércio de idéias com a Europa, vindo a impor-se, no seu lugar, uma orgulhosa atitude de isolamento em relação ao exterior. Os únicos contatos com a ciência moderna durante quase três séculos teriam sido apenas "assaltos" esporádicos "de piratas beneméritos".

Essa forma de problematizar a questão viria a ser retomada noutros ensaios, sempre com o mesmo intuito de crítica ${ }^{2}$. Em 1925, logo depois da Antologia dos economistas portugueses, António Sérgio apresentou uma conferência sobre "As duas políticas nacionais", defendendo a retomada de um verdadeiro programa de "fixação"; em Coimbra, no ano seguinte, veio a público o "O Reino Cadaveroso ou o problema da cultura..."; mais tarde, apareceu um pequeno livro sobre o desenrolar da experiência portuguesa, onde se resumiam alguns dos pontos de vista já conhecidos ${ }^{3}$. O último capítulo da segunda parte era inteiramente dedicado à "intervenção renovadora dos "estrangeirados", que o autor esboçava com grande simplicidade.

"...Portugal e suas colonias formavam (...) um sistema fechado, em que a metrópole, parasitando, pudera viver no isolamento em relação às idéias que animavam a Europa. A grande maioria da Nação, que estava integrada nesse sistema, detestava esses homens de superior cultura, esses pioneiros de uma idéia nova, a quem apodava de 'estrangeirados'. (...) (A estes se deveu, em suma, tudo o que se fez de bom em Portugal nos reinados de D. José e D. Maria I, e no Brasil no tempo de D. João VI). ${ }^{\prime A}$

"Na natureza do pensamento ensaístico, o acento está colocado não sobre o objecto, mas sobre o método, pois não se trata de aprofundar para objectivar mas sim de problematizar para criticar...". BARRETO, Luis F. - Pensando Sérgio. Brotéria. 106 (5-6): 563, maio/junho 1978 (gf. do texto). V. tb. SÉRGIO, António - Prefácio à segunda edição (1956)". Ensaios. $2^{\circ}$ ed. Lisboa, Liv. Sí da Costa Ed. 1977, Tomo 2, p. 1-15.

3 Para acompanhar o desenvolvimento dos grandes temas identificados por esse autor, V. Sá, Victor de. A historiografia sociológica de António Sérgio. Lisboa, Instituto de Cultura Portuguesa. 1979. $110 \mathrm{p}$.

4 SÉRGIO, António. Breve interpretaçäo da história de Portugal. 12^ ed. port. Lisboa, Liv. Sá de Costa Ed. 1985. p. 121 (O período citado entre colchetes nâo constava da edição espanhola de 1929). 
MIRANDA, Tiago C.. P. dos Reis. "Estrangeirados". A questão do isolacionismo português nos séculos XVII e XVIII.

Cada vez mais, os argumentos de António Sérgio obedeciam a uma disposição maniqueísta, no interior de um quadro com uma longevidade dramática. A ótica de um historiador emprestaria ao assunto um aspecto bastante diferente...

A clássica dualidade entre "estrangeirados" e "castiços" só foi consagrada por Jaime Cortesão em 1950, como resultado de uma longa pesquisa sobre as negociações que levaram ao Tratado de Madrid. Outra vez no Rio de Janeiro, voltava a florescer a questão do encontro de Portugal com a "modernidade européia". No entanto, assumia-se uma perspectiva mais específica que a de António Sérgio, pois a idéia do "estrangeirado" vinha facilitar o entendimento de uma estrutura político-social determinada, em meados do século XVIII.

Vale notar que o Professor do Instituto Rio Branco admitia limitações a esse modelo conceitual. Na sua opinião, os "estrangeirados" teriam defendido muitas vezes posições contraditórias, ao pretenderem conciliar valores "antigos" e princípios "modernos" 5 . Além disso, a existência de importantes religiosos que procuraram desenvolver o espírito científico da Igreja e de suas escolas tornava difícil apontar um projeto "anti-clerical" coerente e homogêneo ${ }^{6}$. Perspicaz, Jaime Cortesão chegou mesmo a discutir a suposta "clarividência" de alguns reformadores. Segundo ele, havia quem tivesse sido "profundamente desnacionalizado pela educação estrangeira", passando a avaliar a realidade nacional com parâmetros que definira em situações de outra natureza. Era o caso, por exemplo, de um famoso cristão-novo dedicado à medicina...

"...Quando, cerca de 1759, (António Ribeiro) Sanches escrevia as suas Cartas, vivia há mais de trinta anos no estrangeiro. Residira longamente em Inglaterra, na França, na Holanda, na Itália, na Rússia. Hebreu de sangue e estrangeirado pela demorada formação, e renovação intelectual nesses paises, ele não compreendia nem podia compreender o seu país de origem. E o que sucedia com ele, acontecia com muitos outros estrangeirados. 
Quando apelidava o governo português de 'Monarquia Gótica' (no sentido de bárbara e antiquada) por não subalternizar bastante as suas colônias, julgava estreitamente Portugal pelo critério racionalista e friamente utilitário, que então dominava na Europa para além Pirineus. Mostravase incapaz de descortinar os valores morais e espirituais, específicos, a que obedecia a nação. Certamente, Portugal menosprezava, com dano próprio, as atividades agrícolas e comerciais, que outrora haviam criado uma burguesia, capaz de influir e tonificar a política nacional. A crítica nesse ponto era certeira. Pecava apenas por carência. Em Portugal, acima dos interesses do comércio e dos cálculos da burguesia, embora por vezes coincidindo com eles, haviam prevalecido sempre outros valores: uma fé religiosa, estreitamente fundida com a fé politica da nação."

Apesar de tudo, o entusiasmo de Jaime Cortesão com os "estrangeirados" ainda parece coincidir com o de António Sérgio num ponto relevante: para ambos, foram eles os "pioneiros de uma idéia nova" - em alguns casos, autênticos "percursores" do espírito liberal ${ }^{8}$. É obviamente escusado questionar a fragilidade dessa avaliação, realizada a posteriori; no entanto, ela apresenta interesse porque denuncia a mesma crença no correr da história e aponta uma dívida muito semelhante quanto ao debate intelectual desenvolvido a partir de 1808 .

2. Os acontecimentos que levaram a emigração da Corte para o Brasil, atingiram fortemente as instituições e o comércio do Reino português. Se é verdade que já há algum tempo se começara a sentir uma certa defasagem em relação aos maiores centros europeus, o advento das guerras napoleônicas criou a necessidade de reconhecer grandes erros de conduta no passado. Um deles fez-se logo muito claro: no momento em que houvera recursos, o país mostrara-se incapaz de promover o conjunto de reformas que o restante do continente havia descoberto. Sem rumo, Portugal abandonara o seu honrado lugar "na proa da história", chegando ao cúmulo de ser invadido pelo estrangeiro.

$7 \quad$ Idem. p. 106-107.

8 Idem. p. 124. 
MIRANDA, Tiago C. P. dos Reis. "Estrangeirados". A questấo do isolacionismo porluguês nos séculos XVII e XVIII.

A urgência de um debate que pudesse trazer soluções, incentivou o aparecimento de novos órgãos de imprensa. Em Londres, por exemplo, ergueu-se um jornal que procurava divulgar as artes e as ciências, refletir sobre as novidades políticas e reaver os melhores testemunhos da literatura nacional; chamou-se $O$ Investigador Portuguez, e foi criado com o apoio do ministro do Brasil na Corte de Inglaterra. A redação compunha-se por três médicos: "...Abrantes, que em 1809 estivera prêso na Inquisição de Lisboa (...); Nolasco, fugido das iras de Junot por ter saudado a Casa de Bragança numa reunião maçônica; e Castro, brasileiro, formado em Edimburgo...", que decidira permanecer em Londres, onde viera a constituir família. Em 1813, a chefia passou à responsabilidade de José Liberato Freire de Carvalho, igualmente perseguido no Reino 9 . Foi esse grupo de "marginais" que realizou as primeiras impressões das cartas de Alexandre de Gusmão e José da Cunha Brochado, além dos escritos do embaixador português ao Congresso de Utreque, D. Luís da Cunha. Entre eles, logo no segundo número do jornal, encontrava-se o ofício a Marco António Azevedo Coutinho sobre a oportunidade de uma mudança da Corte para o Brasil ${ }^{10}$.

Poucas vezes $O$ Investigador revelava a origem dos seus documentos literários. Ao que parece, eram obtidos de acordo com a iniciativa dos próprios jornalistas ou a colaboração de correspondentes fiéis. Talvez a maior parte saísse de copiadores da nobreza e da Igreja, relativamente comuns na segunda metade do século XVIII; porém, o fato é que muitos textos corriam em diferentes versōes, sem se terem ao certo localizado os originais: nalguns casos, é lícito questionar a sua autenticidade. Mesmo valorizando particularmente o renome dos autores e a conveniência da mensagem, os responsáveis pelo Investigador chegaram a abordar esse problema. Em março de 1815 , confessavam imprimir uma cópia de um decreto real de 1732 , sem que o remetente houvesse esclarecido onde o encontrara ${ }^{11}$. No número seguinte, publicaram-se as três famosas cartas de Carvalho e Melo a William Pitt sobre o incidente de Lagos, admitindo claramente que não se tinham visto "as originais"; de qualquer maneira, sequer se parecia duvidar que "o grande Ministro Portuguez" exigira uma reparação formal ao governo da

9 RIZZINI, Carlos. Hipólito da Costa e o Correio Braziliense. São Paulo, Companhia Editora Nacional. 1957. p. 41-42.

10 O Investigador Portuguez em Inglaterra... Londres, H. Bryer Imp. agosto de 1811. p. 399-409 (exemplar da Biblioteca Nacional de Lisboa).

11 Idem. março de 1815. p. 82-84. 
Inglaterra, pela agressividade da sua marinha ${ }^{12}$. Atualmente, essa hipótese é considerada bastante improvável ${ }^{13} \ldots$

A obra do Marquês de Pombal começaria a receber divulgação significativa em 1820, quando se acentuou o clamor por grandes reformas político-sociais. Na mesma altura, deu-se à luz um Testamento Político de D. Luís da Cunha. De acordo com Pedro de Azevedo, seguiu-se-lhe parte das Instruçôes ao Príncipe D. José, que em 1808 já teriam sido referidas por Robert Southey ${ }^{14}$. O interesse desses trabalhos foi exaltado ao longo de todo o século XIX, defendendo-se constantemente a publicação dos extratos que ainda se guardavam em acervos da Coroa e em Bibliotecas particulares.

Igualmente famosas, as cartas do secretário de D. João V, Alexandre de Gusmão, só foram reunidas num único volume em 1841, na cidade do Porto. Estamparam-se também nessa época algumas reflexões acerca dos impostos sobre o ouro do Brasil, dos cristãos-novos e do Tratado de Madrid, além de pequenas obras literárias, cuja autoria se discute. A iniciativa mereceu grandes aplausos d' $O$ Panorama, numa resenha em que se levantava a possibilidade de imprimir outros escritos de Alexandre de Gusmão, tomando por base as cópias do Convento de Nossa Senhora de Jesus (ocupado pela Academia das Ciências) e as informações que pudessem ser levantadas no Rio de Janeiro junto ao Visconde de São Leopoldo, estudioso da matéria ${ }^{15}$.

12 Idem. abril de 1815 , p. $183-184$.

13 V. ALMEIDA, Luís F. de, res. SEBASTIÄO JOSÉ DE CARVALHO E MELO - Memórias secretíssimas do Marquês de Pombal e outros escritos. Publicaçöes Europa-América. "Estudos e documentos", $\mathrm{n}^{2}$ 193. Mem Martins, s.d. (1984). 323 p. Revista Portuguesa de História. Universidade de Coimbra, XXI: 203-206. 1984. Para a correspondência trocada entre Londres e Lisboa naquela altura, ARQUIVO NACIONAL DA TORRE DO TOMBO - Ministério dos Negócios Estrangeiros. Cx. 691 (1758-1759) e 692 (1760-1761), e BIBLIOTECA NACIONAL DE LISBOA-Coleção Pombalina. Cod. 634.

14 FINGANIERE, Jorge C. de. Bibliographia Historica Portugueza... Lisboa, Na Typographia do Panorama. 1850. p. 88, e (CUNHA, D. Luís da) - Instruções Inéditas de D. Luis da Cunha a Marco António de Azevedo Coutinho. Rev. de Pedro de Azevedo e Pref. de António Baião. Coimbra, Imprensa da Universidade. 1929. p. V-VII. Para a análise de uma reedição do texto de 1820, ALMEIDA, Luís F. de, res. - Testamento Politico de D. Luiz da Cunha - Prefácio e notas de Manoel Mendes. Cadernos da "Seara Nova". Biblioteca do Século XVIII. Lisbon, 1943. Vol. de 107 págs. Revista Portuguesa de História. Coimbra. III: 468-500.

15 O Panorama. Jornal Litterario e Instructivo da Sociedade Propagadora de Conhecimentos Uteis. Lisboa, Typ. da Sociedade. jan.-dez. 1841. p. 392. Innocencio F. da SILVA sugere que o autor da nota fosse Varnhagen (Diccionario Bibliographico Portuguez. Lisboa, Imprensa Nacional. MDCCCVIII. T. I. p. 34). 
MIRANDA, Tiago C.. P. dos Reis. "Estrangeirados". A questão do isolacionismo português nos séculos XVII e XVIII.

Em meados do século, a vitória do projeto liberal e o aumento da atividade da imprensa transformaram alguns personagens da história portuguesa em símbolos exclusivos de um dos grandes blocos do espectro político. Encaminhado já em 1820, foi apenas no auge do romantismo que esse processo se definiu com uma clareza maior. Figuras como a do Marquês de Pombal viram-se cada vez mais citadas no discurso dos "progressistas" ${ }^{16}$. Não deixa de ser revelador que em 1855 as C'artas de Francisco Xavier de Oliveira (herege e libertino), conhecessem uma primeira reedição portuguesa.

Anos mais tarde, na altura em que crescia o interesse pela filosofia da história, começou-se a compreender a experiência nacional como se ela tivesse obedecido a uma lógica evolutiva: da juventude à senilidade. Os nomes mais significativos da geração de 70 identificaram os séculos XVII e XVIII com o luxuoso espetáculo da monarquia, o apreço da ociosidade e a temária escola jesuítica. Durante muitos anos, Portugal e Espanha teriam vivido isolados do resto da Europa. Abrir as portas ao exterior e respirar as idéias da revolução seriam a única forma de vencer o obscurantismo e renovar a prática econômica.

Os primeiros grandes textos correspondendo a esse movimento surgiram nas Conferências do Casino Lisbonense, em 1871. Vale referir com destaque o trabalho de Antero de Quental, intitulado "Causas da decadência dos povos peninsulares". Nele, mostrava-se como a originalidade dos tempos medievais e do início da Renascença fora destruída pelo catolicismo tridentino, pela opressão absolutista e pelo abandono da terra. Durante quase três séculos, os romances picarescos e as comédias populares teriam sido praticamente os únicos espasmos de vida numa sociedade desmoralizada; para além deles, só valeria a pena registrar alguns casos pontuais, como os de D. Francisco Manuel de Melo, do Cavaleiro de Oliveira e de Alexandre de Gusmão $^{17}$.

A imagem da Península em ruínas teve em Joaquim Pedro de Oliveira Martins seu melhor divulgador. Para ele, o declínio começara antes mesmo do abraço de 1580 , prolongando-se fatalmente pelo século XVII, até ao

16 TORGAL, Luis M. S. dos R.. Pombal perante as ideologias tradicionalistas e catolicas. In: SANTOS, Maria H.C. dos (coord.) - Pombal revisitado. Lisboa, Ed. Estampa. 1985. Vol. I, p. 131-157.

17 QUENTAL, Antero de. Causas da decadência dos povos peninsulares. (1871) $2^{\mathrm{a}} \mathrm{ed}$. Lisboa, Cadernos Peninsulares, 1971. p. 25, 28-29 e 55-56. 
reinado "brasileiro" de D. Joẫo $\mathrm{V}^{18}$. Anos depois, o Marquês de Pombal ainda tentaria desenvolver um novo projeto; no entanto as bases do seu trabalho mostrar-se-iam inadequadas, posto que demasiado estranhas ao espírito da nação.

"O Portugal de D. José (...) era um falso Portugal de importação, nas ideias, nas instituições, nos homens. ${ }^{19}$

Essa extrema sensibilidade no que toca ao nacional e ao estrangeiro foi característica dos dois últimos quartéis do século XIX. Na obra de Antero de Quental, por exemplo, o sonho do universalismo era acompanhado de um grande respeito pelos sentimentos populares e locais, que o poeta acreditava deverem desabrochar naturalmente... As crônicas "inglesas" de Jaime Batatha Reis mencionavam com freqüência o curioso desdém dos súditos britânicos por tudo o que destoasse do nacional ${ }^{20}$. Por outro lado, Eça de Queiroz incluia nos seus romances personagens que não correspondiam à "maneira de ser "portuguesa'", tanto na fala, como no trajar. Quando o Primo Basílio visita Luiza pela primeira vez, é significativo como Juliana, observadora, identifica logo a presença de um "estrangeirado"...

A importância de levar a intelectualidade nacional a um diálogo mais constante com a Europa, fora sublinhada, entre outros, por Luís António Vernei, em meados do século XVIII. Depois dos primeiros estudos com Jesuítas e Oratorianos em Lisboa e Évora, o Barbadinho conseguiu instalarse em Roma, onde escreveu a maior parte de uma obra fortemente polêmica. No seu Verdadeiro Método de Estudar, chamava a atenção para o desconhecimento da moderna filosofia e acusava os centros universitários portugueses de hostilizarem o estrangeiro. Segundo António Alberto de Andrade, Vernei foi relembrado elogiosamente ainda na década de 1820, por Fr. Bernardo de São Boaventura, da Academia das Ciências; entretanto, o resgate no trabalho

18 MARTINS, Joaquim P. de Oliv. História de Portugal. (1 $1^{4}$ ed., 1879) $16^{2}$ ed. Lisboa, Guimarães Ed. 1972. Liv. Sexto, Cap. V ("As minas do Brasil..."). p. 436-457. V. tb. História da Civilizaçâo Ibérica. (1ª ed., 1879) $11^{2}$ ed. Lisbon, Guimarâes Ed. 1984. Liv. Quarto, Cap. VII ("Causas da decadência dos povos peninsulares") e Liv. Quinto ("As ruínas"), Cap. I e II. p. 253-2.92.

19 IDEM. História de Portugal. p. 488. Para uma boa leitura desse capítulo, V. LOURENÇO, Eduardo - Pombal e Oliveira Martins. In: SANTOS, Maria H. C. dos - Supra cit. p. 159-166.

20 REIS. Jaime B.. Revista Inglesa.(Crónicas). Org., introd. e notas, Ma. José Marinho. Índices, Júlia Ordorica. Lisboa, Publicaçóes D. Quixote/Biblioteca Nacional. 1988. p. 11-12, 73, 123, 125,138 e $145 . \mathrm{M}^{\mathrm{a}}$ José Marinho lembra que essa opinião a respeito dos ingleses também se poxle encontrar em Oliveira Martins, Ramalho Ortigão e Eça de Queiroz (p. 11-12). 
MIRANDA, Tiago C. P. dos Reis. "Estrangeirados". A questão do isolacionismo português nos séculos XVII e XVIII.

de José Joaquim Lopes Praça, bem como nos de Ricardo Jorge, Ferreira Deusdado e Teófilo Braga parece ter sido mais duradouro ${ }^{21}$. A mensagem do Barbadinho conferia nova autoridade aos argumentos liberais e republicanos, ajudando a associar a Monarquia e a Igreja a uma velha imagem de estagnação e isolamento. Aqueles que procuraram combatê-la no século XVIII, teriam sido acusados de defender línguas "estranhas" e princípios diabóli$\cos .$.

"D. Luiz da Cunha (por exemplo) era homem de grandes planos e vastas ideas; mas viveu sempre em um tempo em que os grandes commetimentos eram taxados de estrangeirismos, e mal aceitas as inovações. ${ }^{22}$

Só assim se explicava que alguns dos seus melhores escritos ainda se conservassem inéditos.

3. A dívida para com intelectuais da segunda metade do século XIX foi abertamente reconhecida por António Sérgio. Na conferência de 1913, as epfgrafes pertenciam a Alexandre Herculano e Antero de Quental, que juntamente com Vernei seriam os grandes representantes do moderno pensamento português. Além disso, António Sérgio ainda nutria uma considerável admiração pela obra de Oliveira Martins, embora discordasse de várias de suas hipóteses. Entre outras, pareciam-lhe muito pouco convincentes as interpretações de natureza rácica ${ }^{23}$; tinha uma certa dificuldade em esconder alguma simpatia pelo reinado de $\mathrm{D}$. João $\mathrm{V}$, que assistira à grande epopéia dos sertões americanos e formara homens "notabilíssimos"; finalmente, denunciava o ataque sistemático ao papel da Companhia de Jesus, como uma enorme mentira social ${ }^{24}$. De qualquer forma, a quase orgânica noção de decadência e a imagem de isolamento no contexto europeu foram por ele reiteradas.

21 ANDRADE, António A. de. Vernei e a cultura do seu tempo. Coimbra, Universidade de Coim bra. 1966. p. 450, e tb. Luiz António Vernei; crítico e primeiro historiador português da filosofia. Brotéria. Lisboa. XXXVIII (4): 421-441. MCMXLIV (entre outros artigos). PRAÇA, José J.L. - História da Filosofia em Portugal $\left(1^{\circ} \mathrm{ed}, 1868\right) 3^{\circ} \mathrm{ed}$. Lisboa, Guimarães Ed. 1988. p. 242-249.

22 LEAL, Augusto S. d'A.B. de P.. Portugal antigo e moderno. Lisboa, Liv. Ed. Mathos Moreira \& Cia. 1874. Vol, Quarto, p. 328.

23 V.Sá, Victor de. Opus cit. p. 86-90.

24 SÉRGIO, António. Correspondência para Raul Proença. Org. e introd., José González. C/ um estudo de Fernando P. Santos. Lisboa, Publ. D. Quixote/ Biblioteca Nacional. 1987. p. 187 (Carta de Genebra, 1916). 
A pobreza e o desânimo dos séculos XVII e XVIII também ecoaram nas obras de João Lúcio d'Azevedo, para quem, na altura, os únicos canais de comunicação com o restante do continente eram aqueles que viajavam sem ser incomodados pelo aparelho inquisitorial - grosso modo, diplomatas e comerciantes de prestígio ${ }^{25}$. A nível de filosofia e ciência, autores como Newton de Macedo, Luís de Pina e Hernâni Cidade elogiaram a reação contra a escolástica seiscentista e o acolhimento das idéias que no século XVIII frutificavam para além dos Pirineus ${ }^{26}$. Entretanto, aos poucos, o velho grupo de "estrangeirados" começou a reunir um número maior de eclesiásticos.

Na década de 50, José Sebastião da Silva Dias, levado pela "...necessidade de colher informes, adquirir noções exactas, tanto quanto possf́vel objectivas e sem fumos de preocupação polémica, que permitissem compreender melhor a crise nacional do século XIX", também acabou por se ver envolvido com a questão da moderna cultura portuguesa ${ }^{27}$. Mais uma vez, impunha-se a tarefa de analisar os caminhos que haviam transportado ao país as novidades da Europa. O trabalho confirmou a existência de um certo intercâmbio intelectual no século XVII, embora o autor viesse a concluir que uma das conseqüências dessa permeabilidade tenha sido "...uma espécie de cisão entre indígenas e estrangeirados". O embate dos dois partidos ocorrera principalmente na Corte, desdobrando-se pelas escolas. Em resumo, José Sebastião da Silva Dias procurava incorporar os últimos resultados da investigação desenvolvida por setores de origem católica, sem desprezar o esquema interpretativo de António Sérgio e Jaime Cortesão. É pois bastante compreensível que o artigo encerrasse propostas dificilmente conciliáveis... 28

A idéia de que Portugal deveria suas melhores realizações a um grupo de "estrangeirados" foi sugerida de maneira especialmente alargada por António Coimbra Martins. Apesar de reconhecer que a definição do conceito levantava obstáculos, acabava concordando em aplicar o termo ao longo de quatro séculos de história. Com as Luzes, a análise d'além-fronteiras teria adquirido inclusive um valor singular...

25 V., p. ex., O Marquês de Pombal e a sua época. $2^{\mathrm{B}}$ edição c/emendas. Rio de Janeiro, Annuario do Brasil; Lisboa, Seara Nova; Porto, Renascença Portuguesa. 1922. p. 87-88.

26 V. PERES, Damião (dir.). História de Portugal. Barcelos, Portugalense. s/d (1928-37) Vol. VI., e CIDADE, H. Lições de cultura e literatura portuguesas. Coimbra, Coimbra Ed. 1939. Vol. 2. p. 19-133.

27 Portugal e a cultura européia. Sec. XVI a XVII. Separata da Revista "Biblos". Vol. XXVIII. Coimbra. MCMIII. p.v.

28 Idem. p. 70, 79-80, 99, 118, 116, 255-6, 259. 
"... o atributo de estrangeiro pôde então ser considerado, por certos maitres à penser europeus, condição prévia da lucidez judicante. Nas Lettres Persannes, de Montesquieu, a França é descrita por viajantes persas. Mais tarde, em L'Ingénu, de Voltaire, será criticada pela inteligência, pura e imparcial, desprevenida, de um selvagem americano. Assim se convida cada leitor a estrangeirar-se, isto é, a olhar com olhos não cúmplices, com olhos de estrangeiro, para o seu próprio pais. ${ }^{129}$

Sob o governo de Marcelo Caetano, o assunto voltou a estar relacionado com alguns debates políticos importantes; o reconhecimento e a admiração de um velho grupo intelectual que ousara extrapolar os limites nacionais, também passou a fazer parte das críticas contra a mentalidade que então se manifestava em defesa do império africano e asiático, ou em favor da Igreja. Na obra de António José Saraiva, é basicamente a ilustração do exterior que permite compreender o movimento de idéias que levou ao fim dos cristãosnovos (matéria-prima essencial para a máquina do Santo Ofício) ${ }^{30}$. Em Joaquim Barradas de Carvalho, a lembrança dos textos de Ribeiro Sanches recuperados com emoção através "do grande António Sérgio" -, viria a transformar-se em citation à l'ordre du jour, no corpo de um breve trabalho sobre Portugal, a Europa e o Atlântico.

"..."E agora? Agora, no século XX? Agora, estamos na mesma. Relativamente no mesmo estado. Não nos illda a existência de portugueses excepcionais, que se educaram nos laboratórios e nas leituras dos estrangeiros. A cultura autêntica, a cultura crítica, não impera ainda em Portugal!'(Somos o 'Reino C'adaveroso'; somos o 'Reino da Estupidez'. Não digo isto para desanimar: bem ao contrário; pois nesta mesma cidade em que estou falando, e nos próprios campos onde aloura o trigo, se pressente já um arrebol. (Vingará? Não sei.) Portugal, por enquanto, é ainda o Reino da Estupidez: mas espero

30 SARAIVA, António J.. A Inquisição e os cristãos-novos. (1 $1^{\circ} \mathrm{ed}$, 1969) $4^{\circ} \mathrm{ed}$. Porto, Ed. Inova Ltda. 1969. Cap. XII ("Como e porquê acabaram os criståos-novos em Portugal?"). 
R. História, São Paulo, n. 123-124, p. 35-70, ago./ jul., 1990/1991.

para breve (e para muito breve) a aurora do dia em que o não será." 31

De forma semelhante à de alguns homens do século XVIII, Joaquim Barradas de Carvalho passou longos anos da sua vida no exílio. Pouco antes, vários intelectuais portugueses conheceram o mesmo destino: entre eles, curiosamente, António Sérgio e Jaime Cortesão, que também estiveram na França e no Brasil... Foi no estrangeiro que eles formularam boa parte de suas críticas; foi no estrangeiro que conheceram mestres e reencontraram amigos; foi lá que sentiram particularmente as conseqüências de uma política censória, exclusivista e totalitária, sustentada por algumas das mais antigas instituições do país.

4. A historicidade do tema parece ter despertado relativamente pouco interesse entre brasileiros, embora autores como Gilberto Freire e Sérgio Buarque de Holanda tenham discutido questôes semelhantes. As referências a um grupo de "estrangeirados" costumam ocorrer em pesquisadores de formação estruturalista. Na década de 70, por exemplo, Fernando António Novais e Francisco Calazans Falcon - dois dos mais brilhantes estudiosos do Império Colonial Português no século XVIII -, adotaram a tipologia elaborada pelos seus colegas d'além-mar. As reflexões que o primeiro dedicou ao assunto incluem algumas importantes ressalvas: a impossibilidade de se falar num isolamento absoluto, a existência de uma política externa coerente no reinado de D. João V, o papel modernizador dos Oratorianos e a especificidade de certos casos, tais como os do Cavaleiro de Oliveira e dos "luso-brasileiros". No correr do trabalho, esses dados ajudam a caracterizar os antecedentes da política ilustrada na governança da colônia sul-americana, e suas contradiçōes ${ }^{32}$.

Francisco Falcon, por outro lado, estabelece um caminho mais próximo ao de António Sérgio, conferindo à categoria dos "estrangeirados" um lugar central no seu estudo sobre a "época pombalina". Existe na sua tese uma rápida história das apreciaçöes negativas do universo cultural português nos séculos XVII e XVIII, com referências a obras de Cunha Brochado, Matias

31 A primeira parte do texto é referida por CARVALHO, Joaquim B. de. Rumo de' Portugal. A Europa ou o Atlántico? (Uma perspectiva histórica). Lisboa, Livros Horizonte. 1974. p. 80-81, n. 41. Os colchetes principais indicam a sequência, conforme SÉRGIO, António - O Reino Cadaveroso e o problema da cultura e'm Portugal. In: Ensaios. T. II (supra cit.). p. 28.

32 NOVAIS, Fernancto A.. Portugal e Brasil na Crise do Antigo Sistema Colonial (1777-1808). ( $1^{\text {a }}$ ed., 1979) $2^{\circ}$ ed. Sâo Paulo, Ed. Hucitec, 1983. p. 219-224. 
MIRANDA, Tiago C. P. dos Reis. "Estrangeirados". A questão do isolacionismo português nos séculos XVII e XVIII.

Aires e Ribeiro Sanches; além disso, lembram-se os trabalhos de Jaime Cortesão, Silva Dias, António José Saraiva, Óscar Lopes e Hernâni Cidade ${ }^{33}$, antes que o problema volte a ser retomado algumas páginas adiante. É grande o entusiasmo que o autor por ele manifesta, reconhecendo, entretanto, a sua dificuldade.

$\mathrm{Na}$ análise de Francisco Falcon, o "estrangeiramento" aparece com o desenrolar de um longo processo de recusa do exterior, definindo uma atitude mental característica do português, que ao fim e ao cabo é um dado empiricamente inquestionável...

"...os estrangeirados existem, são importantes, representam as novas idéias, têm uma visão ampla, criadora, são dotados de capacidades intelectuais que os fazem necessários d monarquia. ${ }^{134}$

Mais uma vez, o ponto alto da nova mentalidade setecentista em Portugal, pertence a Luís António Verney. Francisco Falcon desqualifica as reservas de António Alberto de Andrade e José Sebastião da Silva Dias a esse respeito, conferindo pouco relevo às evidências de intercâmbio cultural com o exterior na segunda metade do século XVII e no início do século XVIII. Tal período seria caracterizado pelo isolamento da intelectualidade peninsular e pelo conseqüente atraso em relação às Luzes da França e da Inglaterra; para o autor, só defende o contrário quem realmente se mostra empenhado em prová-lo ${ }^{35}$... Entretanto, estará aí o fulcro da questão?... Em que medida aceitar a existência de um grupo de "estrangeirados" pode, na verdade, constituír um obstáculo para compreender alguns aspectos da modernidade portuguesa?

5. Os critérios utilizados para definir o conjunto de indivíduos que ora se analisa nem sempre são claros, variando entre o político, o sócio-económico e o cultural. Existe pouco rigor metodológico, faltam pesquisas biográficas, e em certos casos as informações disponíveis sofrem uma seleção que tende a menosprezar elementos discrepantes.

33 FALCON, Francisco C.. A Época Pombalina (Política Econômica e Monarquia Ilustrada). São Paulo, Ática 1982. p. 201-210.

34 Idem. p. 319-323 e 483-490.

35 Idem. p. 331-332. 
Quando se retrata um "estrangeirado", dificilmente se lembram as saudades que ele tinha de sua terra e o lugar primordial que ela continuava a ocupar na formulação de sentimentos corriqueiros, ou dos projetos mais elaborados. Mesmo no exílio, boa parte continuava a viver basicamente em função de Portugal. Suas críticas poderiam ser uma tentativa de difundir no Reino algumas das práticas conhecidas no exterior; entretanto, em muitos aspectos, a "visão de mundo" permanecia inalterada. É bastante curioso que em Londres, no século XVII, ao se referir ao sol, o Marquês de Nisa lamentasse os cinco anos desde que pela última vez o admirara "como Deus o criou" ${ }^{36}$...

Outro "estrangeirado" cujo comportamento parece desafiar a "tipologia" de Sérgio e Cortesão é o bacharel António Freire de Andrade Encerrabodes. De seus escritos, pouco foi impresso. Ao que tudo indica, a maioria dos historiadores portugueses apenas conhece a carta que Alexandre de Gusmão lhe enviou no dia 16 de fevereiro de 1750, para Londres, "aonde se acha livre de Animaes, que o molestavăo, e goza da liberdade, que deus conferio ao homem, sem offender os preceitos de sua Lei". Espirituoso e altivo, comenta o remetente logo depois:

"Não se esqueça V.S. dos amigos que aqui deixou lutando com as ondas do mar da superstição e da ignorância, e agradeça aos seus inimigos o mimo de que atualmente goza. Eu também havia de descompor os meus, se tivesse a certeza de merecer-lhes semelhante destêrro. ${ }^{, 37}$

Cortesão veio a encontrar Encerrabodes no lugar de Juiz da India, ajudando o seu amigo secretário a obter um atestado de pureza de sangue ${ }^{38}$. Aproximadamente na mesma altura, também ele aferiu a inexistência de mácula entre os avós de Luís António Verney ${ }^{39}$. A escritora Agustina BessaLuís e José Sebastião da Silva Dias mencionam alguns ofícios que o Encer-

36 In: PRESTAGE, Edgar. Portugal, Brasil e Grä-Bretanha (Lição inaugural, realizada no King's College, Londres, em 8 de Outubro de 1923). Coimbra, Imprensa da Universidade. p. 25, p.44 ("...A luz do sol que eu não tenho visto há cinco anos como Deus a criou").

37 GUSMÃO, Alexandre de. Collecção de varios escriptos ineditos políticos e literários..., que da à luz pública J.M.T. de C. Porto, Na Typographia de Faria Guimarães. 1841. p. 68-69.

38 CORTESĀO, Jaime. Opus cit. Vol. Il. p. 429-430.

39 ANDRADE, António A. de. Opus cit. p. 21, 531 e segs. 
rabodes enviou para Carvalho e Melo entre 1748 e 1750 , conservados na Coleção Pombalina ${ }^{40}$; entretanto, segundo os parâmetros habituais, os elèmentos referidos não ajudam a sustentar a idéia de que o bacharel fosse "estrangeirado". As cartas que ele dirigiu a Diogo de Mendonça Corte-Real e a Martinho de Mello e Castro levantam inclusive algumas suspeitas em contrário... Embaixador em Haia - próximo ao fim da carreira - era com grande desencanto que analisava as consequências de suas viagens:

"... Hum homem que depois da chicana legal viveo entre protestantes, e depois entre Romanos, $q^{\mathrm{e}}$ nã̃ sey saõ peyores, naõ hé grande cauçaó dos interesses de V. $S^{\mathrm{a}} \ldots^{\prime \prime}{ }^{41}$

Sem ir muito longe, esta observação faz lembrar que também existiam diversos "modelos" no exterior. Durante a década de 1740, D. Luís da Cunha - embaixador em Paris - e Carvalho e Melo - representante em Londres -, sustentaram diferentes idéias sobre os negócios estrangeiros de Portugal. No campo da política interna, as divergências não eram menores: uma vez Secretário de Estado, Carvalho e Melo empenhou-se em afastar os diplomatas que haviam servido a D. João V; ajudou a desacreditar Alexandre de Gusmão, e envolveu-se no processo contra Diogo de Mendonça Corte Real, homem do governo com grande popularidade junto aos embaixadores residentes em Lisboa.

O grupo de personagens identificados pela historiografia abrigava ainda conflitos puramente pessoais, como no caso do Conde Tarouca e do Cavaleiro de Oliveira. Aliás, talvez fosse interessante recordar que esse episódio acarretou graves suspeitas sobre a conduta de dois italianos empregados na representação portuguesa de Viena, chegando-se a discutir a possibilidade de alta traição. Francisco Xavier, enciumado, parece ter mesmo sugerido que os irmãos Valmagini estavam a par de negócios mais recomendados à discrição de um nacional, que ao caráter de estrangeiros ${ }^{42} \ldots$

40 BESSA-LUIS, Agustina. Sebastiāo José. (Lisboa), Imprensa Nacional. 1981. p. 56 (p.ex.), e DIAS, José S. đa Silva - "Pombalismo e projecto político". Sép. da Reve. "Cultura, história e Filosofia". Lisboa, s.n. 1984. p. 189, n. 222 (p. ex.).

41 A.N.T.T. - M.N.E.C. Cx. 6, M⒉ Carta familiar de A.F.A. Encerraboxles para Martinho de Mello e Castro. Haia, 9 de novembro de 1756. f. 1 (v). Está em curso un pequeno artigo com base neste material.

42 RIBEIRO, Aqulino. "Prefácio". In: OLIVEIRA, Cav. de - Cartas. (1ed., 1942) $3^{\circ}$ ed. Lisboa, Liv. Sá da Costa Ed. 1982. p. XIX. 
Entre os muitos funcionários do Império, há aqueles que apesar de importantes habilitações biográficas, nunca chegaram realmente a fazer parte do invejável panteão dos "esclarecidos". Um exemplo interessante é o de D. Manuel de Saldanha, membro da alta nobreza. As notícias a seu respeito começam por volta de 1734, quando foi nomeado gentil-homem do Infante D. Manuel. Após seis anos, o desdobramento de uma questão amorosa levouo a trocar a companhia dos "estrangeirados" de Belas ${ }^{43}$ pelo exílio da Corte de Viena d'Áustria, onde pôde reencontrar Manuel da Silva Teles e Sebastiâo José de Carvalho e Melo. Iniciando-se um novo reinado em 1750, Saldanha obteve autorização para regressar a Portugal, vindo a ser destacado para o governo da ilha da Madeira, antes do terremoto de Lisboa. Os serviços aí prestados valeram-lhe o título de Conde da Ega e o posto de Vice-Rei da India, na seqüência de velha tradição familiar. Durante seu governo, estabeleceu uma rede de alianças com os monarcas locais e advogou o desenvolvimento de uma política baseada em resultados de ordem comercial, já que esse seria o único modo de conseguir um maior número de colaboradores... No fim de 1766, de regresso à Corte, foi preso sob acusação de malbaratar as riquezas da Coroa, tendo-se-1he confiscado todos os documentos pessoais. Mais uma vez, a causa da desgraça parece avizinhar-se do antigo Secretário d'el Rei D. José ${ }^{44}$, que assim apagou a memória de outro personagem de destaque.

6. Algumas destas contradições foram engenhosamente exploradas pelo Professor Jorge Borges de Macedo, num ensaio cuja tese central já não era novidade em $1973^{45}$. Segundo ele, o conceito de "estrangeirado" começou a afirmar-se após as guerras napoleônicas, constituindo uma expressão de crítica e denotando corrupção (de valores). Seu alcance inicial era basicamente de natureza política. Em seguida, viveu "uma existência indecisa e apagada": pôde ser usado para identificar um modo de vestir, uma forma de escrever ou um conjunto de idéias "artificiais" e descabidas. De qualquer

43 V. C.ORTESÃO, Jaime. Opus cit. Vol. I, p. 129-130.

44 SALDANHA, António de S. e V. S. de (org. e introd). As cartas de Manuel de Saldanha, $1^{\circ}$ Conde da Ega e $47^{\circ}$ Vice-Rei da Índia a Selnastiäo José de Carvallo e Melo e seus imños (1758-1756). Subsídios para a história política, económica e social da f́ndia portuguesa de setecentos. Lisbon, Gabinete Português de Estudos Humanísticos. 1984. 310 p.

45 V., p. ex., MAC.EDO, Jorge B. de. "O pensamento económico do Cardeal da Mota. Centribuiçâo para o seu estudo." Separata da Revista da Faculdade de Letras. Lisboa, III Série، 4:79-97. 1960. Problemas de história da Indústria portuguesa no século XVIII. (1' ed., 1963) $2^{4}$ ed. Lisboa, Ed. Querco. 1982. p. 63-64 e "Nobreza (na época moderna)". In: SERRĀO, Joel (dir.) Opus cit. Vol. 1V. 1971. p. 156. 
maneira, levou muito tempo até que começasse a exprimir a ação de uma "força dinâmica e ordenada na história portuguesa" 46.

Borges de Macedo explica que o termo adquiriu sua conotação atual a partir da década de 1910, quando o problema do "atraso" em relação ao exterior passou a ser denunciado por um grupo de intelectuais significativo, com destaque para António Sérgio.

"...Para resolver o atraso, no seu entender, tanto de atitude como de informação (mais do que atraso, erro de via), preconizava uma acção pedagógica no sentido de levar o pats a perder esses defeitos de 'modo e cultura' e a integrarse naquelas formas cientificas que, na tradição do iluminismo, antecipadamente se definiam como as melhores: o experimentalismo. Acrescentava-lhe, no sentido de 'afinar' a capacidade politica, conceitos para a responsabilização individual, através da autonomia das administrações. É neste contexto que apresenta o 'estrangeirado', despido, agora, da ganga das conotações discipiendas que o termo antes possuíra. Envolvia, neste caso, considerações sobre a superioridade de um certo tipo de cultura, a convicção da possibilidade dela vir a aplicar-se ao português, através de propostas 'externas' $e$ as vantagens que dai tiraria. Além disso, definia uma tradição - ainda que mal sucedida para o antagonismo à cultura dominante, mas que dizia errada, além de atrasada: o portador dessa tradição antagonista seria o estrangeirado. ${ }^{47}$

Avaliando alguns trabalhos historiográficos, o autor dá a entender que muitas de suas conclusões não obedecem a critérios analíticos bem definidos. Para ele, há ainda que provar existência de um grupo coeso, com atuação social expressiva, defendendo um conjunto de idéias majoritariamente elaboradas alem-fronteiras...

A obra de Jorge Borges de Macedo requer uma leitura cuidadosa, que talvez se deva acentuar em questões de natureza cultural ${ }^{48}$. No artigo em

MACEDO, Jorge B. de. "Estrangeirados", um conceito a rever. Edições do Templo, s.d. p. 1117.

47. Idem. p. 21 (gf. do texto).

48 V. MACEDO, Jorge B. de. Problemas de história da indústria portuguesa no século XVIII. p. 171 ("...As análises culturais quase sempre soam a simples jogos de palavras quando aplicadas à realidade concreta."). 
questão, o historiador sublinha as grandes controvérsias do mundo acadêmico e os trabalhos de autores consagrados, quase se podendo dizer que o assunto aparece desligado de todas as outras "dimensões (objetivas) da realidade"... Além disso, algumas nuances de sua postura arriscam-se a levantar conseqüências preocupantes. Por exemplo: embora seja verdade que o século XVIII português ainda disponha de um pequeno número de monografias, a defesa das potencialidades do desconhecido fica a meio-caminho de uma cômoda desqualificação de elementos indesejáveis. $O$ fato do autor diminuir o alcance de suas ressalvas nos dois últimos parágrafos (advogando a compreensão de "atitudes estrangeiradas" dentro de um contexto sócio-cultural melhor definido) não deve iludir o caráter essencialmente negativo do seu ensaio, quanto à validade do termo em debate.

Poucos estudiosos assimilaram com clareza as idéias de Borges de Macedo. Numa recente edição de cartas do Cavaleiro de Oliveira, Artur Portela foi um dos primeiros: serviu-se de sua ajuda para trocar o labéu de "estrangeirado" de Francisco Xavier pela categoria de "aventureiro" ${ }^{49}$. Joaquim Veríssimo Serrão - mais entusiasta - discutiu o problema no quinto volume de sua Histôria de Portugal, concordando com a maioria das ressalvas de Jorge Borges de Macedo, além de referir as contribuições previamente elaboradas por António Alberto de Andrade. No correr de algumas páginas, relembrou a importância dos intelectuais da Renascença Portuguesa, aludiu ao distanciamento dos "estrangeirados" em face da realidade nacional e destacou o papel modernizador dos Oratorianos ${ }^{50}$. Por trás desta atitude revisionista, existe um objetivo bastante claro: reabilitar os reis da terceira dinastia, "...por tudo quanto fizeram para manter o prestígio do País." ${ }^{51}$...

Sem produzir muitas das generalizações condenadas por Borges de Macedo, Charles Boxer parece estar convencido da operacionalidade do conceito em questão. Para ele, o intervalo de 1640 a 1750 foi um momento de "estagnação e contração" a Oriente e "renascimento e expansão" a Ocidente. De qualquer forma, a nível cultural - e no seu conjunto -, o Império ressentiu-se das atividades do Santo Ofício, da falta de textos impressos e da quase inexistência de contatos com a moderna ciência européia, denunciadas

PORTELA, Artur. Cavaleiro de Oliveira, aventureiro do século XVIII. (Lisboa), Imprensa Nacional. 1982, $184 \mathrm{p}$.

50 SERRÃO, Joaquim V.. História de Portugal. (1` ed., 1980). $2^{\mathrm{t}}$ ed. rev. Lisboa, Ed. Verbo. 1982. Vol.V (1640-1750). p. 414-418.

51 IDEM. "A génese e o valor da Monarquia em Portugal". In: GRÉMIO LITERÁRIO, Lisboa Estudos sobre a Monarquia. Lisboa, 1984. p.211. 
MIRANDA, Tiago C. P. dos Reis. "Estrangeirados". A questâo do isolacionismo português nos séculos XVII e XVIII.

por alguns membros da nobreza e da alta burguesia ${ }^{52}$. No final da década de setenta, ao traçar mais algumas linhas da biografia de D. Luís de Meneses, $1^{\text {g }}$ Marquês do Louriçal, o historiador britânico insistiu em definí-lo como "estrangeirado", procurando mostrar em que medida suas idéias eram contrárias ao posicionamento dos "castiços". As evidências que reuniu, sugerem, entretanto, que a leitura da historiografia citada realizou-se de maneira a evitar contradições. O uso do livro de António Alberto de Andrade é disso um bom exemplo ${ }^{53}$.

Para que o problema ganhe uma outra coloração, talvez seja interessante aplicar-lhe um enfoque menos restrito ao Portugal da Idade Moderna, questionar alguns valores que sobre ele se vêm desdobrando com o avanço do liberalismo e, finalmente, discutir o estatuto do "estrangeiro" nos séculos XVII e XVIII, tanto no que se refere à Península Ibérica, como ao exterior. Em meio a esses tópicos, o sabor da língua, a conotação das palavras e as imagens que elas ocultam também é um elemento a considerar. Está no idioma uma das peças fundamentais da identidade, como aliás observou um outro membro da Renascença Portuguesa: Fernando Pessoa ${ }^{54}$.

7. Se as comunidades humanas parecem ter uma certa dificuldade em assimilar o que lhes é "estrangeiro", considerando o "outro" como inferior ${ }^{55}$, no século XVI essa questão apresentava desdobramentos particularmente significativos. A lide com entrepostos africanos e asiáticos, a descoberta da América, a construção das monarquias absolutas e o fim da grande comunidade religiosa européia conferiram ao problema da alteridade um lugar de destaque. Em termos gerais, o Estado Moderno ergueu-se em prejuízo do "diferente", do "particular" e do "estrangeiro". Ainda durante o século XVII, eram comuns os panfletos em que se difamavam os inimigos políticos e

52 BOXER, Charles R.. O Império Colonial Português (1415-1825). (1 $1^{\mathrm{e}} \mathrm{ed}$. inglesa, 1969) $2^{2} \mathrm{ed}$. Trad., Inês S. Duarte. (Lisboa), Ediçōes 70. (1981). 406 p. (V. especialmente os Cap. XV e XVI, p. 323-356).

53 IDEM. "The Conde da Ericeira and Beauvollier de Courchant. 1721-1722". Bulletin des Eutudes Portuguaises et Brésiliennes. Nouvelle Série. Tomes 37-38. 1977-1978. p. 39, n. 11.

54 PESSOA, Fernando. Portugah, Sebastianismo e Quinto Império. Pref., introd., notas e org., António Quadros. (Mem Martins), Publicações Europa-América (1986). p. 62-63.

55 "A primeira reação, espontânea, em relaçẫo ao estrangeiro é imaginá-lo inferior, porque diferente de nós: não chega a ser um homem, é um bárbaro inferior; se não fala a nossa língua, é porque não fala nenhuma, nâo sabe falar, como pensava ainda Colombo. Assim os eslavos cha Europa chamam o alemão vizinho de nemec, o mudo; os maias de Yucatán chamam os invasores toltecas de numob, os mudos, e os maias de cackchiquel se referem aos maias nam como 'gagos' ou 'mudos'...". TODOROV, Tzvetan - A conquista da América; a questâo do outro. Trad., Beatriz Perrone Moisés. St̃o Paulo, Liv. Martins Fontes Ed. Ltcla. 1983. p. 73-74. 
religiosos, através de um mecanismo relativamente novo: a imprensa. Foi assim na Inglaterra, na França, nas Espanhas, na Suécia, na Rússia, nos estados alemães e italianos... Nos grandes centros do saber, esperava-se que o desejo de chegar à compreensão dos segredos mais elevados obedecesse a certos limites; só aos poucos é que as noções de "risco" e "novidade" foram universalmente reconhecidas como necessárias ao trabalho intelectual ${ }^{56}$.

A forte intolerância com que os portugueses trataram os judeus no século XVI, de certa forma, contrastou com uma relativa boa vontade no que se refere ao exterior. Como assinala a historiografia liberal, aproximadamente até 1580, na sequência de uma longa tradição, vários estudiosos puderam frequentar as melhores universidades européias. Em território americano, a Coroa portuguesa admitia a entrada dos estrangeiros que se mostrassem interessados em trabalhar, permitindo-lhes desenvolver atividades comerciais, desde que se obrigassem a pagar dez por cento de imposto e a desistir do tráfico com os indígenas ${ }^{57}$. Para Gilberto Freyre, as origens dessa atitude cosmopolita associavam-se às circunstâncias da própria formação do Reino português; acentuando-se por motivos geográficos, encontravam-se suficientemente registradas nos velhos compêndios de normas legislativas, onde inexistiam os direitos de albinágio, detração e naufrágio. Se os privilégios concedidos a mouros e judeus desapareceram com $\mathrm{D}$. Manuel, foi por razóes de ordem religiosa, não por pura xenofobia. Quanto ao Brasil, segundo o autor, "a política de segregação (...) só a inspirou, no século XVII, e principalmente no XVIII, o ciúme do ouro... 58 .

Antes disso, entretanto, Portugal já conhecera outras importantes mudanças de relacionamento com o exterior. A União Ibérica fizera com que Lisboa deixasse de contar com algumas de suas prerrogativas internacionais, levando os grandes círculos administrativos a perder o antigo convívio com os restantes países da Europa e a animar um forte sentimento de caráter local ${ }^{59}$. No que toca ao comércio, foi ainda no reinado de D. Sebastião que se conferiu aos naturais a exclusividade no transporte de mercadorias para territórios do ultramar. Mais tarde, em 1591, proibiu-se o deslocamento de

56 GINZBURG, Carlo. "O alto e o baixo: o tema do conhecimento proibido nos séculos XVI e XVII". In: Mitos - Emblemas - Sinais. Morfologia e história. Trad., Frederico Carotti. São Paulo, Companhia das Letras. 1989. p. 95-117.

57 HOLANDA, Sérgio B. de. Raíze's do Brasil. (1ªl., 1936) $18^{d}$ ed. Rio de Janeiro, José Olympio Ed. 1984 , p. $74-75$.

58 FREYRE, Gilberto. Crsa.Grande es Senzala. (1ª ed., 1933) $25^{\circ}$ ed. Rio de Janeiro, José Olympio El. 1987 , p. $196-201$.

59 MACEDO, Jorge B. de. "Nobreza (na época moderna)". Supra cit. p. 154. 
MIRANDA, Tiago C. P. dos Reis. "Estrangeirados". A questâo do isolacionismo português nos séculos XVII e XVIII.

barcos estrangeiros aos domínios da Coroa portuguesa, a menos que para tanto se viesse a apresentar uma licença extraordinária.

O prolongamento da guerra com a Holanda contribuiria para intensificar as restrições ao tráfico colonial. No início de 1605 , fez-se necessário confirmar a legalidade das licenças já adquiridas. Pouco depois, Filipe II viria a proibir de maneira taxativa qualquer tipo de comércio estrangeiro com as províncias descobertas, excetuando as ilhas da Madeira e dos Açores. Todos os súditos de outra nação residentes no ultramar deveriam mudar-se para Portugal no prazo de um ano, ficando sujeitos às mais severas punições em caso de desobediência ${ }^{60}$.

Instalados na sua nova morada, não poderiam usar qualquer espécie de arma, nem adquirir naus ou caravelas que se tivessem construído no Reino. Se por outro lado entrassem em desacordo com um homem da terra, fazendoo por isso deter, a acusação seria legalmente derrogada tão logo abandonassem o país ${ }^{61}$.

A vitória separatista de 1640 acarretou um distanciamento da influência cultural espanhola. No campo militar, os esforços da dinastia de Bragança voltaram-se para o resguardo das fronteiras e para a recuperação dos territórios atlânticos e asiáticos. Foi notável, nessa altura, o apoio ideológico da Companhia de Jesus, que enalteceu a figura de D. João IV; um de seus membros mais destacados, Padre António Vieira, chegou a imaginar uma nova comunidade de almas, sob comando português: o Quinto Império...

$\mathrm{Na}$ cena internacional, teve início um período de difíceis relações com a Corte de Roma, que se mostrava inflexível quanto a alguns privilégios que se desejavam assegurar no âmbito das dioceses. Ao mesmo tempo, procurouse garantir a sobrevivência do Reino, voltando a incorporá-lo ao complicado xadrez europeu. Nos anos de 1642, 1654 e 1661, estabeleceram-se acordos decisivos com a Inglaterra. Pouco depois, através dos casamentos de $\mathrm{D}^{\mathrm{a}}$ Maria Francisca de Sabóia, também se confirmaram os laços de amizade entre Paris e Lisboa.

Os sucessos alcançados pela diplomacia portuguesa custaram importantes cessões financeiras, políticas e comerciais. Só o dote de $D^{3}$ Catarina de Bragança incluía os territórios de Tanger e Bombaim, o pagamento de dois

60 REIS, Arthur C.F.. "O comércio colonial e as companhias privilegiadas". In: HOLANDA, Sérgio B. de (dir.) - História Geral da Civilização Brasileira. (1ª ed., 1969) $6^{\circ}$ ed. (São Paulo), Difel. (1985). Tomo I, $2^{\circ}$ Vol. p. 311-312.

61 ORDENAÇŌES Filipinas. Lisboa, Fundaçâo Calouste Gulbenkian (1985). Liv. 5, tit. 80, parag. 5 ; tit. 114, e tit. 123, parag. 7. 
R. História, Sâo Paulo, n. 123-124, p. 35-70, ago./ jul., 1990/1991.

milhões de cruzados e a confirmação dos privilégios recentemente concedidos aos mercadores da Grã-Bretanha. Entre eles, sobressaíam o princípio da liberdade religiosa, o tributo de $23 \%$ sobre as mercadorias entradas em Portugal e a permissão para que quatro famílias inglesas instalassem residência em Pernambuco, na Bahia e no Rio de Janeiro ${ }^{62}$. Mais tarde, durante a Guerra da Sucessão Espanhola, tornar-se-iam a fazer acordos de aliança e amizade com representantes de Londres, confirmando as disposições comerciais do tratado de Westminster e introduzindo a famosa cláusula sobre o estatuto privilegiado dos tecidos de Inglaterra e do vinho do Porto.

Ao analisarem esse panorama, os historiadores liberais e estruturalistas costumam denunciar a "dependência" econômica de Lisboa, que assim veria crescer entre o povo um sentimento de inferioridade, com resultados bastante negativos nas mais diversas áreas da vida nacional. Entretanto, nem sempre se exploraram todos os lados dessa incômoda questão. As cedências comerciais ajudaram a manter a integridade do Reino; as alianças políticas e militares estabeleceram formas de resguardar interesses semelhantes, muito justamente relacionados a um certo temor do poderio espanhol. E como "...se não se entenderem as palavras, naõ podem lerse as acçoens...", talvez também se deva lembrar que no século XVII e no início do XVIII a noção de "dependência" andava ainda muito próxima do que era útil ou conveniente ${ }^{63}$. Em grande parte, a força de um Estado media-se pelas alianças que conseguia sustentar e pela posição que ocupava no equilíbrio europeu.

8. Alguns forasteiros que se deslocaram ao Portugal da dinastia de Bragança, descreveram com detalhe a situação do país e a índole do seu povo. Trata-se de um conjunto de testemunhos bastante heterogêneo. Entre os que estudam essa matéria há quem decida sublinhar as queixas sobre a má conservação das estradas, e inferioridade das estalagens e a ignorância dos habitantes, denunciando ainda a pobreza do exército e as grandes dimensões das counidades religiosas. No entanto, quem quiser construir uma imagem positiva baseada no mesmo gênero de fontes, também encontra elementos. Castelo Branco Chaves mostrou recentemente que essa literatura esteve sujeita a diversas motivações de natureza política, além de muitas vezes

62 REIS, Arthur C. F.. "O comércio colonial e as companhias privilegiadas". Supra cit. p. 312-313.

63 BLUTEAU, P. D. Raphael de. Vocabulario Portuguez, \& Latino... Lisbon; No Collegio das Artes da Cia. de Jesus, Na Officina de Pascual da Sylva e Na Patriarcal Officina de Musica. 1713-1728. T. II, verb. "conveniència", col. 516-517; T. III, verb. "dependência" e "depender", p. 68-69; T. VII, verb. "subordinação", p. 762. A frase citada é do Conde ch Ericeira, na "Censura da Apologia do P. D. Rafael de Bluteau". Supplemento. Parte II, p. 551. 
MIRANDA, Tiago C. P. dos Reis. "Estrangeirackos". A quuestâo do isolacionismo português nos séculos XVII e XVIII.

apenas refletir o desejo de comprovar a existência de uma sociedade intrigante e exótica ${ }^{64}$.

Uma idéia particularmente curiosa defendida por certos viajantes, era a de que os portugueses alimentavam uma grande hostilidade em relação aos estrangeiros. Para citar algumas obras, poder-se-iam referir as Mémoires Instructives de Charles Mérveilleux, a Voyage du ci-devant duc du C'hâtelet e até mesmo as Lettres Persanes. Em sentido contrário, houve testemunhos menos conhecidos. Um deles foi o de Charles Brockwell, antigo morador em Portugal, que escreveu um livro para orientar os súditos britânicos interessados no comércio de Lisboa. Seu tom era determinado:

"...I must in Justice contradict that so much inculcated Notion among us, of their being injurious and base to Foreigners, especially the English, since for whatever Insults or Affronts Foreigners meet with, they must blame theirselves; for by frequent Instances I can aver, they will generously forgive in a Foreigner, what nothing but life shall atone for in a Native..."

Outro forasteiro que deixou elogios à "civilidade" dos portugueses foi M. Link. Para ele, as censuras que se faziam eram "“...abusivamente generalizadas e muito injustas...'". Ao longo de três anos em Portugal, o botánico alemão pôde conhecer diversas regiões do país, analisando as particularidades do campo e da cidade, além de alguns aspectos do comércio, da indústria e das artes. Numa referência ao teatro, observou que as representações no Salitre nem sempre eram de bom nível, exceto no caso das farsas. E concluiu:

64 ('HAVES, Castelo B.. Os livros de viagens em Portugal no século XVIII e a sua projeção euro. peia. (1* ed., 1977) 2‘ ed. Lisboa, Instituto de Cultura e Lingua Portuguesa. 1987. 96 p. V. tb. SANTOS, Piedade B. et alii - Lisboa Setecentista vista por estrangeiros. Lisbon, Iivros Horizonte. 1987.87 p., e C:ARDOZO, Manuel S. - "The Modernization of Portugal and the Independence of Brazil". In: RUSSEL-WOOD, A.J.R. (ed.) - From Colony to Nation; Essays on the Independence of Brazil, Baltimore and London, The John Hopkins University Press. 1975. p. 201 e 203.

65 BIBLIOTEC:A MUNICIPAL MARIO DE ANDRADE - BROCKWELL, Charles - The natural and political history of Portugal. London, Printed for the Author, and sold by T. Warner. 1726. p. 17 (à margem, "Civil to Foreigners"). Essa relativa tolerância quanto à observaçâo das "regras comunitárias" pelos estrangeiros, também foi notach pelo historiaclor Antonio DOMf́NGUEZ ORTIZ no caso de Espanha: "...Los españoles, tan puntillosos cuando se trataba de la ascendencia de sus compatriotas, no escrupulizaban mucho tratánclose de extranjeros..." Sociedad y Esta. do en el siglo XVIII espaniol. (1 ed., 1976) $3^{\circ}$ reimp. Barcelona, EJ. Ariel. 1988. p. 340. 


$$
\text { para a crítica }{ }^{, 66} " \text { "...a nação tende em geral para o espirito } e
$$

Esse juízo faz lembrar aquelas pequenas ressalvas em que os liberais do século XIX viriam a incluir os romances picarescos e as comédias populares. Ao mesmo tempo, permite recordar a existência de uma rica tradição de pregadores e moralistas, que não se coaduna facilmente com o ideal de uma "ortodoxia" impermeável, sustentada pela Inquisição e pela censura literária.

9. Um dos elementos da moderna sociedade portuguesa que levantou constantes polêmicas foi o estatuto dos nobres. Em fins do século XVII, esteve presente nos trabalhos de D. João da Silva Carvalho e do Frei Amador Arrais; mais tarde, andou nas penas de Matias Aires, Diogo Borges Pacheco Pereira e do abade Inocêncio António de Miranda, já influenciado pelos princípios do igualitarismo. Como assinala Borges de Macedo, foi muito próximo desse grupo que surgiram a Arte de Furtar, A Gazeta em forma de C'arta, o Diário de D. Francisco de Meneses, as obras do "Judeu", o Verdadeiro Método de Estudar e a Recreação Periódica do Cavaleiro de Oliveira, entre outros. "Estrangeirados" ou "castiços", vozes dissonantes, num fenômeno de longa duração ${ }^{57}$...

Apesar de discriminação de natureza essencialmente religiosa, os contatos intelectuais do exterior não desapareceram com "o espírito da ContraReforma". Nos mosteiros e nas escolas, continuaram a entrar edições francesas, italianas e holandesas. Da mesma forma que em outros países, o latim resistiu por muitos anos como "idioma de sabedoria"; entretanto, aos poucos, as necessidades do estudo e o convívio com indivíduos de origens diferentes levaram à aprendizagem de algumas línguas modernas.

No segundo quartel do século XVII, as grandes conquistas da astronomia européia foram divulgadas em Portugal pelo Jesuíta Cristóvão Borri. Anos mais tarde, o Padre Henrique Buseu ensinava princípios de mecânica no Colégio de Santo Antão; Francisco Soares Lusitano citava René Descartes; finalmente, uma conhecida polêmica entre dois militares terminava com a menção de um importante estrangeiro:

66 Cit. p/ CIHAVES, Castelo B.. Opus cit. p.31-32 e SANTOS, Piechde B. et atii - Opus cit. p. 69.

67 CARDOZO, Manuel S.. "The Modernization of Portugal and the Independence of Brazil". Supra cit. p. 188, 189 e 202. MACEDO, Jorge B. de - "Nobreza (na época moderna)". Supra cit. p. 156. 
MIRANDA, Tiago C. P. dos Reis. "Estrangeirados". A questão do isolacionismo português nos séculos XVII e XVIII.

"Busque Vossa Mercê o seu Merceno..."

Altos funcionários, clérigos e membros da nobreza fizeram multiplicar nos centros urbanos, reuniōes literárias. Algumas transformaram-se em academias: pequenos universos da moda, entretidos em jogos de estética e sedução, que se poderiam realizar em bibliotecas particulares como a de $\mathrm{D}$. Francisco de Meneses. A partir de 1696, foi ela que abrigou as Conferências Discretas e Eruditas. Depois, assistiu à restauração da Academia dos Generosos, já com maior destaque para o campo da matemática e da filosofia ${ }^{69}$. Impunha-se discutir conseqüentemente os modernos, de forma a reavaliar a doutrina dos antigos.

Na Igreja, o avanço das novas idéias levantou diferentes reações. Em 1706, a XV Congregação-Geral da Companhia de Jesus condenou várias idéias de Descartes. Quarenta anos mais tarde, na Universidade de Coimbra, ordenou-se que os mestres não ensinassem sistemas contrários à realidade dos acidentes eucarísticos, ou que de qualquer outra forma comprometessem a obra de Aristóteles. Essa posição mudaria rapidamente nos anos seguintes; antes, porém, o contato com os modernos ficou registrado nos trabalhos de António Cordeiro, Manuel de Campos, Silvestre Aranha, Clemente Alexandrino e António Vieira (homônimo do pregador setecentista). Na mesma época, os Oratorianos difundiram os seus estudos de física experimental e os Beneditinos começaram a procurar atingir as "luzes" que brilhavam fora dos claustros peninsulares $^{70}$.

O início do século XVIII também marcou o progresso das ciências naturais em terras de Espanha. Os protagonistas do movimento foram conhecidos como novadores: gênios "rebeldes" e "blasfemos", para quem a tradi-

Correspondência de 1652 entre o general Luis Serráo Pimentel (1631-1679) e D. Francisco de Melo (...-1652?).

69 PALMA-FERREIRA, Joño. Academias literárias dos séculos XVII e XVIII. Lisboa, Biblioteca Nacional. 1982. 160 p.

70 RAMOS, Luis A. de Oliv. "Pombal e a reforma dos estudos monásticos. O caso beneditino". Revista de História das Idéias. Coimbra, IV ("O Marquês de Pombal e o seu tempo". II): 113124. 1982. Para uma visåo panorâmica, retomando de certa forma os artigos publicados na Bro. téria nas décadas de 30, 40 e 50, V. COXITO, A. - "Para a história do Cartesianismo e do Anticartesianismo na Filosofia portuguesa (sécs. VII-XVIII). Cultura. História e Filosofia. Lisboa. VI: 23-28. 1897 ("... a verdade é que muito haveria a dizer sobre as repercussões, no século XVIII, de doutrinas como a de Gassendi, Port-Royal, Malebranche, Leibniz, Locke, Newton e Wolff, entre outros, e sobre o seu impacto na Escolástica entâo vigente. Isso demonstraria que essa época significou na cultura portuguesa uma agitação intelectual deveras interessante e libertadora, ainda que cheia de perplexidades e contradições." p. 23). 
ção deixara de representar o caminho da verdade. Benito Feijó esteve na primeira linha dos debates então realizados, enfrentando adversários que, como ele, possuiam contatos além fronteiras ${ }^{71}$. Para Domíngues Ortiz, esse e outros dados comprometem a possibilidade de explicar o fenômeno pelo acolhimento a doutrinas oriundas do estrangeiro. Parece mais interessante considerar a existência de diferentes graus de compromisso entre a obra dos antigos e o desejo de novas soluções, num momento em que se fazia necessário justificar maior racionalidade em termos econômicos e um sentido mais prático na direção dos assuntos do Estado.

10. Sobre o ecletismo setecentista na Península Ibérica, e mais determinadamente em Portugal, cabe ainda recordar um indivíduo cujo trabalho sempre mereceu grande admiração: o Padre Rafael Bluteau. Nascido em Londres, de pais franceses, teve a oportunidade de cursar as escolas de La Flèche e Clermont, indo depois para Reims e Paris. Mais tarde, estudou em Florença, Verona e Roma. Seguiu para Lisboa como Teatino no ano de 1668, sendo particularmente bem acolhido por $\mathrm{D}^{\mathrm{a}}$ Maria Francisca de Sabóia. Com a morte da rainha, dirigiu-se mais uma vez a terras de França, e só retornou em 1704, quando a Europa guerreava pelo trono de Espanha. Suspeitas levantadas pela sua nacionalidade valeram-lhe nove anos de clausura no Mosteiro de Alcobaça e a chance de redigir uma obra singular: o Vocabulário Portuguez, \& Latino (...).

Em face de uma tão rica experiência internacional, o que era ser "estrangeiro" para o Padre Rafael de Bluteau? Será que ele chegou a formular alguma opinião sobre a observância desse estatuto? De certa forma, pode-se dizer que sim. No próprio Vocabulário, dedicam-se mais de duas colunas à palavra em questão.

Durante os séculos XVII e XVIII, "estrangeiro" era aquele que nascia noutro Reino, tendo assim uma pátria diferente das pessoas com que fora viver. Reconhecia-se pela cara, pelo "acento" ou pelos costumes. Entre os dirigentes romanos, essa condição sugeria inimizade, como se fosse profecia "...que sempre os estrangeiros haviaõ de ser ịnimigos da terra, que naõ fosse sua patria". De qualquer maneira, muitos foram os que ainda lograram ser admitidos a dignidades da República. Se havia um lugar de que eles estavam definitivamente excluídos, era o da realeza, em virtude de uma sentença 
MIRANDA, Tiago C. P. dos Reis. "Estrangeirados". A questão do isolacionismo português nos séculcs XVII e XVIII.

divina: - porque aos Hebreus proibiu o Senhor "... que elegessem para si Rey estrangeiro..." ${ }^{72}$.

Ressalvas à parte, Bluteau fazia questão de aconselhar uma conduta pautadas pelo universalismo de origem cristã:

"...naõ permitte a boa razaõ, que sendo todos os homens nacionaes do ceo, em quanto a alma, \& na terra todos estrangeiros, \& peregrinos, (a) hum homem se faça crime, ou materia de desprezo, o naõ ser natural deste, ou daquelle Reino".

E mais abaixo, acrescentava:

"...O estrangeiro há de ser como a prumagem, que depois de criar raízes, \& dar bons frutos, tem sua estimaçaõ, 7 he tida por planta da terra, em que foi disposta. Os Rios, que fertilizaraõ as nossas terras, vem de muito longe dellas. Fora cousa galante, que naõ quizessem os Portugueses aproveitarse das agoas do Tejo, porque he Rio, que em terras de C'astella tem seu nascimento.

No campo da literatura, o Padre Rafael de Bluteau também procurava apoiar contribuições vindas de fora. Para ele, seria conveniente que os portugueses mantivessem uma certa proximidade com os outros idiomas nascidos do Latim, já que a semelhança favoreia a inteligência, e o aumento do número de bons livros em italiano, francês e castelhano ajudava a melhor satisfazer o interesse dos leitores. Paralelamente, Bluteau defendia a incorporação de algumas palavras estrangeiras, que por ele foram chamadas "pertendentes" 74 . Menos tolerante, contudo, mostrou-se Diogo Barbosa Machado: na sua Bibliotheca Lusitana (1741-1759), ao nomear os portugue-

72 Saul, primeiro rei de Israel, foi escolhido em tempo de guerra contra os Filisteus, para melhor julgar e dirigir o povo do Senhor: "...Eis que o Senhor te ungiu por príncipe sobre a sua herança e tu livrarás o seu povo chs mâos clos seus inimigos, que o cercam. E este será para ti o sinal de que Deus te ungiu príncipe". Anos mais tarde, Davi receberia a promessa de um reino eterno. $\mathrm{Li}$ vros dos Reis. 1-10, 1 e 11-7, 11-16. O assunto apresenta clesdobramentos cle interesse em várias passagens do Antigo Testamento.

73 BLUTEAU, Raphael de. Opus cit. T. III (1713). p. 332-333.

74 Idem. Supplemento. Parte II (1728). p. 535-538 e 555-558. 
ses que tinham contribuído para o esplendor da cultura nacional, excluiu propositadamente o Teatino. Ao fim e ao cabo, as águas podiam separar-se pelo nascimento...

A segunda edição do dicionário de António Moraes e Silva, em 1813, definiria o "estrangeiro" de uma maneira mais propícia às novas regras do Direito Internacional: "O que nasceu em terra estranha, e não é naturalizado naquella onde reside". Entre os termos afins, talvez se pudessem mencionar o "afrañcezádo" e o "aframengado". Este já era conhecido pelo menos desde o início do século XVIII, designando "Aquelle que tem cara de f'ramengo, ou de estrangeiro alvo, e louro". O primeiro só se deve haver tornado comum no auge do iluminismo, e referia alguns aspectos de ordem mais propriamente cultural ${ }^{75}$. Corresponde ao momento em que o Santo Ofício e a Real Mesa Censória aumentaram a repressão aos ideais revolucionários que se fortaleciam em determinados pontos da Europa.

11. Quem procura ver no moderno português uma atitude especialmente negativa frente ao "estrangeiro", lembra que a palavra também denotava o "estranho" e o "alheio ao natural". Contudo, isso não é uma particularidade lusitana, nem peninsular. Os dicionários alertam que o termo é de origem latina (extraneus), vindo a expandir-se com o francês arcaico: estranger, étranger, étrange - ce qui n'est pas de la même nature .... Em inglês, o problema é ainda mais interessante, e envolve as palavras strange e foreig. ner. Pelo menos até ao século XVIII, foi muito difícil uma distinção entre elas; ambas designavam alguma coisa que vinha de fora ou que não parecia "normal". No século XVII, já se usavam derivações como estranged, estrangedness, stranger e foreignize. Com as "Luzes", tenderam a firmar-se conotações mais exclusivas ${ }^{76}$.

Desde a época dos Tudor, a Inglaterra acostumou-se a ser acusada de manter um relacionamento bastante difícil com o exterior. Relatos franceses denunciam que os súditos da Casa de Bourbon estavam sujeitos a uma série de restrições extraordinárias quando negociavam em portos de nacionalidade britânica ou espanhola ${ }^{77}$. Nos grandes centros urbanos, eram freqüentes as

75 SILVA, António de Moraes. Diccionario de Lingua Portuguesa (fac-simile da $2^{\mathrm{s}}$ ed. -1813 ). Photographada pela "Revista de Lingua Portuguesa"; direção, Laudelino Freire. Rio de Janeiro, 1922. V.I.

76 The Compact Edition of the Oxford English Dictionary. Complete text reproduced micrographically. Oxford, At the Clarendon Press. 1971. V. 2, p. 3082.

77 BONOLAS, Pierre. "La question des étrangers à la fin du XVI ${ }^{e}$ sieccle et au début du XVII siècle". Revue d'histoire et contemporaine. Paris, XXXVI. Avril/ juin, 1989. p. 314-315. 
MIRANDA, Tïago C. P. dos Reis. "Estrangeirados". A questão do isolacionismo português nos séculos XVII e XVIII.

manifestaçöes populares em que se levantavam palavras-de-ordem contra os inimigos de outras naçöes: ainda no fïm do século XVIII, a populaçäo de Londres bradava contra irlandeses, espanhóis, portugueses, italianos e franceses. Parte da hostilidade era uma decorrência do fervor religioso, que entretanto se achava intimamente ligado à própria identidade nacional ${ }^{78}$. Da imagem de tolerância construída por liberais, podem-se inclusive questionar algumas idéias sobre o tratamento dispensado aos judeus. Afinal, o Jewish Nationalisation Act de 1753 motivou protestos em que ate se chegou a referir a necessidade de proteger $a$ honra da religião cristä ${ }^{79}$...

Se é verdade que os embaixadores portugueses na Corte de St. James mostravam respeito e admiração pelo poderio de sua aliada, não é menos certo que alguns de seus valores lhes causassem estranheza. O tratamento dispensado aos forasteiros é disso um bom exemplo. No ano de 1758, ao noticiar que D. João de Bragança estava de partida para Viena d'Áustria, Martinho de Mello e Castro comentava com o Secretairio D. Luís da Cunha:

"... 'posso segurar a V. Ex.' (...), q em todo o tempo que (ele) aqui residiu me deu a grande satisfaçä de o ver bem recebido, e annado de toda esta Naçaõ, circunstancia $q$ poucos estrangr. ${ }^{\text {os }}$ conseguem nesta terra'... ${ }^{\text {"so }}$

Anos antes, em 1741, Carvalho e Melo confidenciaram num relatório para Lisboa que o estatuto de estrangeiro mostrava-se, na Inglaterra , "... mais do que em todos odiozo..." 81 .

12. Houve diversos intelectuais portugueses que se chegaram a queixar da elite do Reino por ela ser exageradamente receptiva ao que vinha do exterior. Nas cartas de José da Cunha Brochado, existem críticàs à tendência de "idolatrar o que se (...) cobre com o sagrado nome de estranjeiro...".

78 RUDÉ, George. Paris and London in the Eighte'mh Century. Studies in Popular Protest. (1" ed., 1969). New York, The Vinking Press. 197.3. 350 p.

79 CORTESÃO, Jaime. Opus cit. Vol. II, p. 462 ("Otserve-se que esta explosio ou fingida explosão de ólio anti-semita partia dum e'strangeriroklo (Martinho de Menckonça), formado numa cultura -a inglesa, que timbrava pela tolerîncia em tal matéria...").

80 Of. de 31 de janeiro de 1758. Cit. p/CARVALIIO, Rómulo de. D. Jorio Cirlos de Bragrm̧̧a, .3? Duque de Lafö́'s. Lisbon, Academia clas C'ièncias de Lisboa. 1987. p. 17.

81 ARQUIVO HISTÓRICO ULTRAMARINO - Ministério (k Reino. M" 2023 (1740-1754). Of, de Sebastião José de Carvalho e Melo provavelmente dirigido a Marco António de Azevedo Coutinho. Londres, 18 ke julho de 1741 ? Incompleto. 
abatendo, por outro lado, "...tudo o que é nosso..." ${ }^{82}$. Em 1754, o Jesuíta Inácio Soares lembrava que os nobres de Portugal "...têem lisongeado a França com a eleição que fazem daquele Reino para exemplar de cultura e civilidade ..." ${ }^{83}$. Poucos anos depois, Lopes Caldeira remetia a Gregorio Mayans opinião no mesmo sentido, a respeito do velho Conde da Ericeira: "...'tratava melhor os am. ${ }^{\text {os }}$ de fora, do q os de caza'"; e concluia: "Suponho que assim são todos os Senhorōes Portuguezes ${ }^{\prime \prime} 84 \ldots$

$\mathrm{O}$ acesso a pessoas e a objetos do exterior era um sinal de prestígio gostosamente cultivado pela nobreza. Nesse aspecto, aliás, ela reproduzia uma das principais características do estado Barroco, que se desenvolveu em Portugal de maneira particularmente ostensiva no reinado de D. João V. Sua Corte, organizada sob inspiração da etiqueta de Françá, veio a ser importante lugar de convivio entre diferentes nacionalidades.

Segundo Rui Bebiano, o aparato do novo cerimonial chocou os fidalgos mais acostumados ao silêncio e à austeridade que por muito tempo existiram nos palácios da Coroa. Embora já no reinado de D. Pedro II se tenham assistido a grandes celebrações da monarquia, foi apenas no período seguinte que a força da mudança permitiu a observadores como José da Cunha Brochado visualizar dois grupos claramente distintos: o primeiro, renovador, encabeçado pelo Conde da Ericeira; o segundo, "defensor do mais purificado decoro", por D. Francisco de Paula Portugal e Castro, Senhor do Título de Vimioso ${ }^{85}$.

Indícios de profundas transformações começaram a surgir logo em 1708 , durante as cerimônias de recepção à Rainha D ${ }^{\mathrm{a}}$ Maria Ana d'Áustria. Numa carta familiar ao representante de Lisboa em St. James, o Conde D. Luís Manuel da Câmara noticiava que as festas haviam corrido com toda a grandeza. A Rainha fora recebida por D. João e pela Corte, desembarcando numa estrutura especialmente fabricada para esse momento. Depois do culto religioso, ceara-se em público mais de uma vez. Nos dias seguintes, os monarcas passaram a comer em particular, "...mas com licença p." (que)

82 BROCHADO, José da C... carlas. Seleç̧̂̃o, Pretácio e Nolas, Anlónio A. Dória. Lisbon, Liv. Sí da costio Ed. p. 76, 157-158.

83 "Corolárius" (u Philosophia Universa Eclectica. Cit. p/GOMES, J.P.. "Perante novos sistemas e novas descobertas". Brotśria. Lisboa. XXXIX (5): 30,3-304. MC'MLIV.

84 Cit. p/ PIWNIK, Marie-Hélène. Echangès Erudits dans Ia Peninsule Iberique (1750-1767). Paris, Fondation Caloustre Gulbenkian/ Centre Culıurel Portuguais. 1987. p. 201.

85 BE:BIANO, Rui. D. Joảo $V$ - poxler e espetáculo. Apresentação de Luís Reis Torgal. Aveiro, Liv. Estante. 1987. p. 57-65, 104-108. 
MIRANDA, Tiago C. P. dos Reis. "Estrangeirados". A questâo do isolacionismo português nos séculos XVII e XVIII.

fidalgos, e Estrangeros pudessem assistir". Ordenando-se um espetáculo de fogos de artifíco, foi permitido acompanhar o deslocamento da Rainha e das Senhoras até às janelas do quarto de Sua Majestade, "... couza q ha m. ${ }^{\text {to }}$ tempo senaố logrou na nossa Corte...". Por fim, no dia de S. Carlos, realizouse um grande baile, onde as Damas do Paço cantaram para os nobres. Na visão de D. Luís da Câmara, todo esse aparato era muito significativo:

"...El Rey esta teimado em estrangeirar o nosso País, e ate gora (sic) o vai conseguindo apezar das grandes repugnancias $q$ a isto tem todos os nossos Ministros, Ds. $o$ conserve na opinião $p^{\mathrm{a}}$. que por tempo vinhamos, a parecer gente..." ${ }^{\prime 86}$.

Algumas questões se levantam aqui. Primeiramente, é interessante referir o uso do verbo "estrangeirar", que lembra a terrível falibilidade dos melhores dicionários, perante o cotidiano da língua... Como segundo ponto, deve-se talvez sublinhar o fato da palavra surgir com conotação positiva em meio a um discurso sobre a etiqueta cortesã: o jovem Conde da Ribeira Grande parece estar aplaudindo uma maior liberalidade nas relações interpessoais, satisfazendo-se bastante com a idéia de uma vida palaciana menos austera. No entanto, esses acontecimentos não despertavam o mesmo entusiasmo em homens que depois viriam a ser conhecidos como "estrangeirados". Ainda em 1708, o ex-embaixador José da Cunha Brochado lamentaria o despropósito das enormes festividades reais; mais tarde, no Testamento Polftico de D. Luís da Cunha, celebrizaram-se as críticas ao luxo e à ostentação 87 .

13. Em outros aspectos, o reinado de D. Joāo $\mathrm{V}$ foi certamente mais cauteloso nas relaçōes com o exterior. O tratado de 1712 provocou um certo incômodo na aliança com a Inglaterra, que o governo francês tentou aproveitar para uma reaproximação. Desconfiando das grandes potências européias, Lisboa manteve porém uma política de neutralidade. As acusações de "francezia" levantadas contra D. Luís da Cunha nos Conselhos de Estado referidos

A.N.T.T. - Manuscritos da Livraria. $N^{2} 60$, doc. 94. Carta familiar de D. Luís Manuel da Câmara a D. Luis da Cunha. Lisboa, 9 de novembro de 1708. 2 ff. mss. Orig. Este docum ento já vem referido em CARVALHO, Rómulo de. - A fisica experimental em Portugal no séc. XVIII. Lisboa, Instututo de Cultura e Lingua Portuguesa. 1982. p. 54. Bebiano, Rui. Opus cit. p. 96-97, 104-105. 
por Alexandre de Gusmão ${ }^{88}$, talvez devam ser avaliadas de acordo com essa diretriz. Ao que parece, deixam apenas entrever, afinal, uma certa inquietude quanto à possibilidade de conciliar o comportamento e os interesses do Império de Bragança com os da Casa francesa de Bourbon. Levantando semel hantes indícios, não é pois muito convincente alegar a existênciá de um grupo de homens que repucliava "tudo o que vinha de fora"...

De maneira geral, se em alguma área, nos séculos XVIl e XVIII, a idéia de "tornar estrangeiro" soava de forma reámente pouco agradável, era no campo juríclico, quando relacionada a uma "justá reação" do soberano.

Para um Estado definido como Reino, onde os homens nasciam súditos de um monarca e fiéis a uma dinastia "natural", "fazer estrangeiro" podia significar a anulação desonrosa de um voto de vassalagem e fïm de uma longa história familiar; no limite, criava a obrigação de pedir ajuda a um outro monarca, sob pena de ser excluído de toda a sociedade civil. Era esse o destino dos criminosos de lesa-majestade, como exemplarmente se verificou no reinado de D. José. O caso mais conhecido loi o de 1758 , havendo a Coroa deixado muito claro - no final do Processo - que os réus desciam à humilhante categoria de "peregrinos e vagabunclos" 89 .

Conhecer personagens que denunciassem "as falhas" de atuação do Estado português muito antes da ofensiva napoleônica e da independência do Brasil. Loi um desejo que acompanhou várias geraçóes. Os que defendiamo acelerar do processo de mudanças, em função de uma experiência "superior" do estrangeiro, consideravam os primeiros críticos verdadeiros arautos. Para os que se preocupavam com a perda de uma certa "vitalidade nacional" e com a ausência de um "rumo" bem definido, a penetração de "valores externos" seria uma das grandes responsáveis pelo ambiente de pobreza e apatia... En algum momento, haver-se-iam perdido os fatores que sustentavam a imaginação de uma identidade coletiva.

is GUSMÃO. Alexandre de. Opus cit. Cartas de Lisboa, aos 2 de fevereiro de 1747 e 11 de fevereiro de 1748.

su) (olleçai de Breves Pontificios e Leys Regias que forä expedidos, e publicados desde o anno de 17.11.. sohre a liberdade das Pessoas, Bens, e' Commercio dos Indios do Brasil (...). Impressa na Secretaria de estacto (1759). Doc. XII. 

XVII e XVIII.

Fenômeno português, fenômeno espanhol. Quando Oliveira Martins dizia que "o espírito nacional" era mais semelhante ao caráter de D. Miguel que ao de D. Pedro, no outro lado da fronteira, Menéndez y Pelayo achava nos galicismos do Padre Benito Feijó sinais de um tempo "...en que pareció que íbamos a olvidar hasta la lengua" ${ }^{90}$. Tentando reerguer o fio da tradição ou melhor escapar à sua influência, é curioso que ambos se tenham preocupado em animar um diálogo de cariz ibérico.

Algumas análises da moderna história da Península desconhecem uma certa unidade político-social luso-espanhola, com princípios e valores bastante diferentes dos da "opção" anglo-saxônica ou da experiência revolucionária francesa. Cobrar do Estado português no século XVII a conservação de direitos individuais ou os resultados de uma autoridade "ordenadora", atuando sobre um conjunto de homens que deveriam demonstrar interesses contraditórios entre si, é uma atitude pouco adequada... Como lembra Richard Morse, a Península Ibérica "escolheu" satisfazer o princípio do bem-comum e equacionar os conflitos sociais de acordo com valores cristãos. $\mathrm{O}$ respeito pela "justa razão" da consciência, na certeza de que o Estado era uma entidade natural - e divina -, ajuda a compreender a rejeiçäo de obras fundamentais em outras paragens, como a de Maquiavel. A certa altura é verdade que esse posicionamento gerou situações difíceis de administrar ${ }^{91}$, mas, por muito tempo, espanhóis e portugueses não se sentiram particularmente angustiados ou diminuídos em face de supostas "vitórias do estrangeiro".

O fim do século XVII e o início do XVIII foi um momento de crise de valores à escala européia. Atacaram-se velhas superstições; questionou-se a autoridade das escrituras; aumentou o número dos que defendiam uma separação entre o religioso e o moral... As primeiras críticas aos grandes sistemas visaram a escolástica de inspiração aristotélica; mais tarde, repudiaram-se as formulações de Descartes, Gassendi e Newton, colocando-se no seu lugar "o espírito sistemático" da Enciclopédia.

E "...Comme il y a du vrai dans tout système, il y a des qualités dans chaque peuple..." 92 .

90 MENÉNDEZ Y PELAYO, Marcelino. Historia de los heterodoxos españoles. (1. ed., 1880 . 1881) Santander, Aldus S.A. de Artes Gráficas. MCMXLVI. Lib. VI, Cap. 1, p. 83.

91 MORSE, Richard. O espellto de Próspero: cultura e idéias nas Annéricas. Trad., Paulo Neves. Apresentaçâo, Antonio Candido. São Paulo, Cia. chas Letras Ed. 1988. Parte 1 ("Pré-história"). p. 21-68.

92 HAZARD, Paul. La crise de la conscience europésene. 1680-1715. (1. ed., 1961). Paris, Fayard. 1989. p. 115-116. 
O homem moderno cultivou o prazer de entrar em contato com os vizinhos d'além-fronteiras, onde apreciava outros costumes e podia reavaliar a opinião quanto aos do seu próprio Reino. Nesse sentido, é claro que houve "estrangeirados" em Portugal, tanto como no resto da Europa. Mais difícil de admitir é que eles integrassem um grupo definido e orgânico, monopolizando as críticas ao "sistema" ou que de alguma maneira quisessem tirar o país de um isolamento asfixiante, em benefício de um "projeto" vindo de fora. Por outro lado, também não é fácil sustentar que os povos peninsulares se mostrassem especialmente adversos ao estrangeiro, ou que ignorassem as novidades científicas e filosóficas ao norte dos Pirineus. As evidências já conhecidas, aliás, ajudam a enfatizar que as idéias estảo no tempo...

Em meio às alternativas presentes nos séculos XVII e XVIII, a certa altura, o Estado português adotou algumas práticas de cortesia que já se tornavam comuns em todo o continente, e que se diziam originárias do Reino de França. No seu conjunto, davam mais brilho à vida palaciana e à figura do monarca, expressando uma autoridade cada vez mais absoluta. Os assuntos da própria Igreja de Roma sofreriam maior influência das Secretarias de Estado. Com D. José, a tendéncia para uma atuaçāo regalista levou a mudanças verdadeiramente extraordinárias; as leis e os decretos anunciavam o fim de uma época de trevas e o início de um tempo de luzes, que se caracterizava por um certo destaque à produtividade e aos fatores de natureza económica. Assim, esqueciam-se os antigos objetivos do Estado e aumentava-se a distancia que o separava da nação. Desenvolveu-se, por essa época, o interesse de conhecer o sistema político e legal de outras tradições, para melhor definir o novo rumo que o país tomava. De qualquer maneira, só aos poucos é que ser "estrangeiro" ou "estrangeirado" adquiriu o abrangente sentido cultural e a dimensão polarizadora que mais tarde ingressou na historiografia.

\footnotetext{
(Este artigo foi concebido e concretizado no correr de investigaçôes a nível de pús-graduaçåo. Muitas de suas idéias ganharam um novo desenvolvimento a partir de conversar com alguns professores do Departamento de História da FFLC.H da Universidade de Săo Paulo. Entre outros, gostaria de agradecer especialmente a Maria Odila Leite da Silva Dias, Laura de Mello e Souza e José Carlos Sebe Bom Meihy, meu orientador. Em Lisbon, pude beneficiar de importantes sugestōes bibliográficas de Evalư Cabral de Mello. A última revisâo do texto ficou enriquecida pela leitura crítica de Luís Reis Torgal. O resultado, como orn se apresenta, é de minha inteirn responsabilidade.
} 
MIRANDA, Tiago C. P. dos Reis. "Esstrangeiraclos". A questão do isolacionismo prortuguès ros séculos XVII e XVIII

ABSTRACT - The analysis of the Portuguese cultural relations in the XVII ${ }^{\text {th }}$ and XVIII ${ }^{\text {th }}$ centuries is the basis of this article. The preocupation in understanding the role of the "estrangeiraclos" and its effect on the Portuguese royal court are explored through the revision of documents from that periol in time, and through a historiographic revision. The "estrangeirados" were, in the Portuguese situation then, intellectuals protected by a state attentive to cultural coherence politics with the rest of Europe. 